\title{
Juggling Roles: Women Teachers Responding to Policy Changes in Education through Trade Union Activitism
}

\author{
Jean Laight \\ Leeds Metropolitan University, UK
}

\begin{abstract}
This PhD work-in-progress explores the impact of the use of unqualified staff on qualified women teachers who are also active in the National Union of Teachers (NUT) in England. The research proposes to investigate how these women conceptualise Teacher Professionalism, gender and trade unionism, whilst also identifying their main concerns. Changes in government and legislation have been rapid and the teaching profession is expected to respond quickly and effectively to a growing number of new initiatives. However, the challenges to teacher professionalism weigh heavy on the workforce, which is predominantly made up of women. Many women teachers in England are finding it increasingly difficult to secure paid work in primary (elementary) schools and settings due to the wide-spread use of unqualified staff to take whole classes. The use of supply agencies has also conspired to marginalize women teachers who work in schools on a casual basis, creating their businesses by taking a percentage of the supply teacher's income and charging the school a fee for supplying the teacher. Whilst developing and using a feminist methodological framework, this work will also follow lines of enquiry into documentary research and policy analysis.
\end{abstract}

\section{Introduction}

The Cameron/Clegg Coalition Government in England continues to allow the practice of unqualified staff to take whole classes, resulting in fewer qualified teachers being employed in schools. Qualified teachers are seeing a reduction in their opportunities for work, whether full-time, part-time or fractional, and many teachers are being forced to leave their chosen profession because they are not able to secure paid teaching work. The voices of the women, who make up the greater part of the teaching profession, need to be heard and listened to and taken into account.

The situation is not without contest. The National Union of Teachers (NUT) became aware of successive government attacks to teacher professionalism and has fought constantly to protect and defend teachers and their work. As the largest teachers' union and the only union of which its members must hold Qualified Teacher Status (QTS), or be in training to achieve this qualification, the NUT continues to fight against the erosion of teacher professionalism. This fight is linked to aspects of the global neo-liberal policy agenda.

Women also make up the vast number of the Executive of the NUT, resulting in the role of National President being dominated by women in recent years. Women who are active in the NUT locally may work voluntarily on committees, promoting the ethos of the NUT in their schools and their geographical regions, or they may be school representatives who cascade important Union information to colleagues in their schools. The General Secretary of the NUT is a woman.

\section{Background - NUT responses}

The number of unqualified staff teaching whole classes continues to rise, while supply teachers are under-utilised and have fast become privatised through the eruption of supply teacher agencies throughout England [1]. Historically, Local Education Authorities (LEAs) would held lists of current supply teachers who could be called upon to teach children at a moment's notice if necessary. These teachers would get to know the school and, more importantly, the children and the staff and the school routines and ethos, often becoming a regular and valued member of the team. Being a supply teacher could lead to regular work and often a permanent contract in the school, if both parties were willing for the relationship to progress in this way.

Supply agencies took away the personal element, failing to match the school with the regular teacher, 
unless specified by the school. LEAs stopped holding lists of supply teachers, consequently losing the essential contacts to enable schools to run smoothly. However, these supply agencies' first priority is to make money, so teachers could be booked and sent to several different schools, making it more difficult for relationships to be established and maintained. Schools would have to pay the supply agency a fee for finding the supply teacher and the supply teacher would have to pay a percentage of their wage to the supply agency for finding them work. As a result, schools began to use the cheaper option of the inhouse teaching assistant who already knew the staff, the children and the school routines. This was a convenient stop-gap, but subsequently became the norm in many schools. Teaching assistants do not need to have the same qualifications or subject knowledge as teachers and were not, in fact, meant to take the place of the teacher but to support the teacher's work and the children's learning.

In contradiction, successive governments have indicated that teachers should be expected to be highly qualified in order to allow children to achieve high standards of learning. Ed Balls formulated 'The Children's Plan' [2], explaining his intention to make teaching a Masters level profession, based on the Finnish model, and Michael Gove is currently following this line. In the recent consultation document 'Training our next generation of outstanding teachers' [3], Gove compares teacher training in England to teacher training in Finland and South Korea, where the results of children's learning are high. He attributes this success to the choice of trainee, citing the practice of taking on only the top third of graduates to train as teachers. This infers that only high-achieving, academically- inclined students could become outstanding teachers. The document makes no mention of qualitative factors such as teacher presence, nor does it discuss the effects that unqualified staff taking whole classes have on children's learning. Gove calls for 'effective teachers' but does not qualify what this term means. The 2010 'Schools White Paper' [4] suggests further changes which continue to challenge teacher professionalism and the nature of teaching. Policies and consultative documents such as these create a smokescreen, directing attention towards plausible possibilities, while privatisation and marketisation, through the introduction of initiatives such as Academies and Free Schools, allow unqualified people to continue to teach children in schools. Blower [5], General Secretary of the NUT, reiterates the fact that the NUT strongly supported the campaign to ensure that the teaching profession secured graduate status. She maintains that teaching is a profession which encompasses skills, knowledge and 'values that come from an understanding of pedagogy'.

As the teaching workforce in the primary sector is largely made up of women, it is significant that it is women who bear the brunt of government intervention. The 2010 Emergency Budget and Comprehensive Spending Review (CSR) has shown deficiencies in the distribution of government spending cuts, leading to the reduction of funding for services and the welfare state as well as jobs. According to the composite motion that was passed at the Women's Trades Union Congress (TUC) Conference 2011 [7], women have been significantly affected by the CSR, and concern was particularly noted about increasing job insecurity, the impact of redundancies, the pay freezes and the substantial cuts to public services, thus causing hardship to families. The gender impact on the government's welfare reforms will cause more women than men to be forced into poverty, particularly in the public sector.

At the Annual NUT Conference 2011 [8], the CSR was also debated in relation to the detrimental effects this is having on women. Relevant motions stated that over $70 \%$ of teachers are women, $65 \%$ of public sector workers are women and that $75 \%$ of local government workers are women. This Conference echoed the concerns of the Women's TUC Conference, stating that the issues were not just about the immediate effects of the government cuts, but that women's equality with men is in danger of regressing. Many women teachers will be greatly affected regarding their job security, given the number on short term or fixed term contracts. Many women teachers will also lose out on their projected pensions, not only because of the proposed government legislation, but also because women are more likely to have had breaks in service during their careers.

\section{Situating the research}

This problem for so many women teachers can be historically situated. In 2005, the Blair Labour Government presented the 'Remodelling the school workforce' document as a response to the stated problem of excessive workload that had been imposed upon teachers [9]. This arose from the prior document 'Raising standards and tackling workload: a national agreement' [10] signed by the government and the unions, with the exception of the largest teachers' union, the NUT. The document identified a 7-point plan to alleviate the burden of increasing workload for teachers, endeavouring to provide a work/life balance. It is argued [11] that teacher professionalism began to be eroded by the 
employment of unqualified staff to teach whole classes, thus bringing the status of the teaching profession into question; the roles and identities of teachers have changed significantly.

Due to the rapid changes taking place, teachers found that their professional identity was becoming uncertain. This fits well with research by Hammersley-Fletcher and Qualter [11] who acknowledge these changes, stating that teachers' perceptions of themselves changed significantly with the onset of the remodelling agenda. No longer did teachers identify themselves as autonomous and responsible professionals, but the introduction of social accountability and consumerism forced teachers to question their professionalism and their sense of purpose. Many teachers have become disillusioned, frustrated and find it difficult to locate themselves within the new roles they have had to take on in order to accommodate the changes. Many teachers have left the profession through resignation or early retirement, consequently experiencing further alienation in their chosen profession.

Some women teachers have chosen an alternative route to teaching by becoming teaching assistants. These women recognise that their vocation is to teach, but due to the harsh reality of the respective government agendas this century, they have decided to work with children in schools in a different capacity. Many such women have opted to become teaching assistants. This means that they can still work with children and are still within familiar frameworks of both curriculum and the physical nature of the school. They have the confidence in their ability, experience and training to take groups of children to support their learning and they do not have the constant worry of meeting targets and deadlines, or staying late for meetings after school and having to plan and prepare during the evenings and weekends.

However, these women do not get paid well. The pay of a teaching assistant is nowhere near that of a teacher so these women make financial sacrifices for peace of mind and solace from the stress of the job. For many of these women teachers who had decided to become teaching assistants, the fewer demands of time and expectations were to be short lived. Once head teachers realised the potential of these women, many decided to use them as teachers but to pay them as teaching assistants. These women found themselves taking on the role of class teacher, of subject coordinator or became in charge of music for the whole school. Gradually they began to give more time to the role in planning and preparation and sometimes even assessment. They began to stay for planning meetings after school, without extra pay, and, in many cases, were taken for granted by the head teacher.

There is further confusion as to the role and identity of the teacher where certain aspects of teachers' work have been brought into question. Gunter and Rayner [12] suggest that the remodelling agenda was not necessarily a response to excessive teacher workload, but rather a means to deregulate the teaching profession. Busy teachers may not be fully aware of the sub texts and challenges of the remodelling process and therefore accept the changes at face value. By allowing other adults to take over what has traditionally become teachers' work, teachers may be parting with core work which cannot be retrieved.

The 24 tasks [10], indicated in the document entitled Raising Standards and Tackling Workload: a national agreement, began to show how teachers' work was being divided up between workers other than teachers. These 24 tasks were considered to be extraneous to the teaching and learning of children and therefore no longer should be performed by teachers. Although this document was originally meant to address the huge workload that teachers appeared to have, it is not as altruistic as it may appear to be. Up until this point, teachers had been leaving the profession in vast numbers because of the demands of extremely heavy workloads. Many teachers also suffered from mental health related illnesses, such as work related stress, resulting in long term absences. The average length of time teachers were expected to remain in the profession was 6 years, which was not deemed by the government to be a viable prospect financially. Experienced teachers as well as early career teachers were also leaving the profession, and it was realised that the reasons were not only the constant and rapid changes that more experienced teachers had to deal with, but also that early career teachers could not withstand the constant pressures of targets and deadlines that were imposed on them.

Through this document, the government began to break down tasks that they did not consider the remit of teaching and learning, thus taking this work from teachers in favour of other workers in the school. The removal of some of these tasks from teachers' duties was welcomed whole heartedly, such as the reduction of unnecessary paperwork, the handing over of bulk photocopying and the collection and recording of money for school meals and trips and other similar routine clerical tasks. Much of this type of work was to be carried out by administration assistants and school bursars, as well as teaching assistants. One of the most significant and welcomed changes in this document was the introduction of dedicated time for teachers in the primary schools to enable them to plan and prepare lessons and to complete assessments. In 
secondary schools, this designated time was always available to teachers during the 'trapped time' between lessons during a normal school day. However, up to this point, teachers in primary schools had always carried out their planning, preparation and assessments after the school day, that is, during the evenings, the weekends and the school holidays, causing a huge work/life imbalance.

The introduction of PPA (Planning, Preparation and Assessment) time was welcomed by primary teachers, as this heralded the possibility of reclaiming the work/life balance that had been missing for so long and had been causing teachers to leave the profession. Teachers were now entitled to $10 \%$ of the working week as non-contact time with children, thus releasing them from the classroom and enabling them to plan, prepare and assess during the actual working day, like their secondary school counterparts. However, other workers were needed to take over the 24 tasks, necessitating further employment and subsequent financial implications. More administration staff were employed to take on clerical tasks and teaching assistants took over many of the other non-teaching tasks which related to the support of teaching and learning.

At this point, roles and responsibilities of teachers and teaching assistants were changing and many teachers felt that their work was becoming more prescriptive and compartmentalised. One aspect of this can be seen in the debate over the responsibility of putting up displays. Historically, teachers had been responsible for organising displays in their own classes and in other areas throughout the school building. Teachers would therefore plan the lessons and would also be aware of the quality and nature of the work they required from the children for display. Once the children's work was finished, the teacher would continue to organise the display, often a process which would evolve as the work materialised. So the process from the planning to the display was an uninterrupted experience, overseen by the teacher, using the skills and knowledge of the pedagogy involved. When teachers were requested to relinquish this responsibility to teaching assistants, many primary teachers were uncomfortable about doing so, seeing the display process as an important aspect of the children's learning as well as a positive and creative part of their role. Feelings of disempowerment and fear of losing their professional identity became familiar to many primary teachers at this time.

Many teaching assistants were uncomfortable about taking over the role of displaying the children's work. As teachers handed over the children's work, which freed precious time for them to continue other teaching, learning and assessment activities, some teaching assistants found the responsibility overwhelming. At best, teaching assistants enjoyed the freedom to display the children's work in a creative way. At worst, they felt that their display skills were not good enough for public scrutiny, causing much personal stress and tension. Relationships between the teacher and the teaching assistant could become strained, as the teacher's intentions for the children's work resulted in a display by the teaching assistant that was not what the teacher had envisaged. At this point in time, many teachers and teaching assistants found the issues surrounding displays very challenging. It was only through working together in an honest and open way that this type of situation could be resolved.

Another example of the changing roles and responsibilities of teachers could be seen through the straightforward task of daily registration. Identified as a clerical task, many teachers had to hand over the registration aspect of the school day to a teaching assistant. Although the purpose of registration appears to simply be that of checking the attendance or otherwise of the children, many teachers use registration time not only to ensure attendance is recorded, but to discuss other information in the register, such as children's birthdays or their addresses in the context of the curriculum. Some teachers like to use this time to foster an awareness of a modern foreign language by asking the children to respond to the register by saying the word 'yes' in French or Spanish. When introducing the concept of time to young children, a teacher may prefix the child's name with 'good morning' or 'good afternoon', facilitating an equally appropriate response from each child. Another popular exercise employed is to introduce the mathematical concept of subtraction by asking such questions as, 'if there are three children away today, how many children do we have here?' Teaching assistants did not necessarily engage with registration in this way, resulting in missed opportunities for incidental teaching and learning experiences. At the same time, teachers began to feel that their roles and responsibilities were being compromised, and that their professionalism was under threat.

The language used by recent New Labour governments has also underpinned the erosion of teacher professionalism. Hayes [13] considers the further deprofessionalisation of teachers by the use of the term 'teacher training' rather than 'teacher education'. He defends the use of the word education as a broad term to describe an academic discipline, rather than the notion of skill-based training. He also makes the point that education is disappearing as a professional subject, making way for 'education studies'. Furthermore, Hayes focuses on the point 
that, under the last New Labour government, the word 'education' was missing from the title of the government department for which it was responsible. This signifies the reality of the continual erosion of teacher professionalism and autonomy over the past 20 years. He compares the narrowness of the current standards-driven teacher training model with the breadth of teacher education, warning that the present government should be mindful that trained teachers rather than educated teachers will not be able to deliver education to children in school.

Furthermore, the correlation between the quality of children's learning and national test results needs to be understood. League tables show that many children are not succeeding in tests, as prescribed by the National Curriculum, making teachers feel guilty and frustrated. The reason for this can be seen in the use of unqualified staff, as they have not been adequately trained to deliver the curriculum as have qualified teachers. Qualified teachers understand the pedagogy surrounding children's learning and are able to gain insight into how children progress, what differentiation needs to take place and what interventions need to be in place in order for children to succeed and thrive. Teachers are trained to know exactly how to support the children they work with to enable maximum success. To qualify for QTS, teachers must possess good subject knowledge in the subjects they teach, as required by the Standards set for teachers by the government, and rigorous skills tests are put in place to test the knowledge of trainee teachers in the core subjects of English and maths. However, support staff do not need to go through such training but are often expected to take whole classes for lessons, unsupervised, thus promoting limited access to the curriculum in view of their lack of subject knowledge and understanding of the subjects and the pedagogy which underpins the necessary learning and teaching for children to learn and succeed.

The current coalition government is proposing that initiatives such as Teach First and School Centred Initial Teacher Training (SCITT) take over from the traditional university-based teacher training model [3]. Gove advocates the use of schools to become the main source of training teachers, but pays no heed to the fact that partnerships already exit between universities and schools. There is little mention of education in the sense that teachers should be educated rather than trained, and the main thrust of the document is one of speed and expedience rather than considered reflection and research.

\section{Rationale}

The main aim of this proposed research is to explore the links between teacher professionalism, trade unionism and gender concerns through interrogating the lived experiences of a sample of women teachers who are active in the NUT. It will explore the struggles of these women in the primary sector, currently and historically, and will consider the thread of feminist issues that underpin professional, trade union and gender concerns in primary teaching and how these elements have been negotiated by these women. The research will explore links between the current and the historical contexts.

There is much debate about teachers' work in the current climate. According to Gunter and Rayner [12], the transformation of the school workforce in England, by the New Labour Government at the beginning of the 21st century, is reminiscent of the performance-driven policies of Thatcher's Government in the 1990s. This transformation emphasised elitist leadership, resulting in the widening gaps between those who had been trained for the main purpose of senior management, and failing to take into account the need for consultation and reflection. They argue that the nature of the transformation appeared to be optimistic, in that some teachers' work would be reallocated to other adults, such as clerical staff and teaching assistants, but in reality, it began to destroy teacher professionalism. Gunter and Rayner [12] also argue that learning, teaching and pedagogy were not taken into account when the changes to the workforce were considered. Therefore the rationale is tied to women teachers' activism and their desire to make changes to enhance to quality of their day to day professional lives and subsequently the lives of the children they teach.

\section{Main research question}

Having experienced personal struggles during my own teaching career, particularly before my own trade union activism began to develop, I am interested to find out what the lived experience is like for activist women teachers today. Time is at a premium for teachers, so my main question is as follows:

How do women teachers who are active in the NUT navigate professional, trade union and gender concerns?

\section{Literature Review}

In order to explore the perspectives and experiences of the sample of women teachers, I will draw on and develop a critical theoretical framework. I shall draw upon an eclectic and socially critical framework, 
including the feminist writer, Moore [14] who discusses gender and status, women and 'domestic labour', women's work, gender and status and women's opportunities. I shall draw on the work of Blackmore and Kenway [15] who argue that, although women make up the vast majority of the educational work force, it is men who are the policy makers. Furthermore, they discuss the issue of teachers' work, echoing themes from Connell [16], and from Arnot and Mac an Ghaill [17]. I will explore the themes of gender and power, as debated by Connell [18], in which concepts of authority, subordination of women across society and force are discussed.

To inform my work regarding teacher professionalism, I will draw on the work of CochranSmith [19] who argues that teachers are currently motivated by fear and have no autonomy, due to the movement that emerged in the 1990s which advocated standards and accountability and has continued to decimate the confidence and status of the teaching profession. Cochran-Smith discusses how political decision making has had a negative effect on the status of teachers, showing how governments define 'good' teachers as those who can pass government tests, rather than by less quantifiable traits.

Connell [20] also discusses the concept of a 'good' teacher, explaining how teachers' voices need to be taken into account by government policy makers. Rather than taking the concept of a 'good mother' into the classroom and professionalising it, Connell suggests that the unique knowledge base that has grown, together with the notion of 'the reflective practitioner', will assist in enabling the improvement of the status of teachers.

Murray [21] also discusses what she calls the 'caring scripts' that women have to negotiate in order to assert their academic and professional status. She explores the gender politics of women educators, focusing on the perceived links and the powerful discourses of child-centred pedagogy with maternity, causing the profession to be feminised. Women teacher educators, as well as women teachers, are among those who face the challenge of established ways of working. According to Murray, women teacher educators work harder than men, devoting more of their time to academic service. They are also positioned as the caring female and substitute mothers to students, a role which is often reinforced through the personal tutor system. This theme stems from the maternal trap that women fall into as they carry their identity as a teacher into their role as a teacher educator, which is not a good role model for the girls and women they educate. So how can women break the cycle of being cast in the caring role in their professional lives, in spite of their research activity and academic profiles?

The issue of teachers' perceived identities is at the heart of research by Hammersley-Fletcher and Qualter [11], who discuss this in the light of the changes which have taken place particularly through the introduction of the government documentation on the Remodelling of the School Workforce in England. They argue that the use of unqualified staff, particularly teaching assistants (TAs), has resulted in teachers feeling that their professional status is threatened. Teachers believe that this initiative, with the inherent rise in levels of accountability, has 'reduced their sense of pride in their professionalism', particularly in the wake of the National Curriculum which founded the culture of accountability and performativity.

Teachers' professional identity, according to Hammersley-Fletcher and Qualter [11], has significantly changed, shifting the formally long-held perceptions of the autonomous professional to that of mere technicians. Teacher identity used to be concerned not only with their occupational selves, but also with their pride in the child-centred approaches they used and their holistic view of the education of the child. However, the emphasis which dominates the education forum is currently that of accountability, competency and consumerism, stripping the former autonomy from the teaching profession and causing stress and concern in teachers' personal and professional lives. The introduction of the new role of the TA, imposing greater responsibility, has resulted in some teachers believing that the erosion of teachers' responsibilities is the thin end of the wedge in deprofessionalisation.

Blatchford et al [12] discuss the increasing use of and investment in support staff, citing the use of TAs mainly as a response to the introduction of the national strategies and the increase in the number of children diagnosed with special educational needs (SEN). The government's concern that teachers were leaving the profession as a result of excessive workload, resulting in the Workforce Remodelling agenda, gave rise to the use of TAs to take over repetitive routine and clerical tasks which had been done by teachers. Although this work was largely welcomed by teachers, being seen as indirect support to children's learning, the government proposed that the role of the TA should encompass a more direct approach. Instead of assisting the teacher in a supportive role, the role of the TA has evolved to take on closer interaction with children, providing alternative support rather than additional support.

Stevenson's [23] research shows that, in spite of the support teachers are given by TAs, they are still experiencing a heavy workload. They still have the 
ultimate responsibility of high stakes, high pressure work and, in fact, state that they used to welcome the mundane tasks, such as photocopying, which provided a break from the intensity and enabled them to recoup their energy. The division of labour between teachers and TAs has caused teachers to find their work highly stressful.

Contesting the continued use of TAs, the NUT has been active in responding to this and other changes that the government reforms have brought. According to Stevenson [23], the rapid changes that have occurred have caused some teachers to feel unprotected by their unions because many teacher unions actively supported the remodelling agenda by engaging with local and national government agencies. Several unions initially joined forces with the government to form a social partnership in order to agree a way forward for teachers in view of the reforms. However, the NUT chose to ignore this partnership in favour of standing alone in opposition to the changes.

To inform my thesis with regard to trade unionism, I shall draw on the work of Davis [24] who presents the case for labour history. She discusses issues such as women's wages and the misguided notion of a 'family wage', earned by the male 'breadwinner', which marginalized women's work and gave widespread rise to inequality in pay. She also discusses ideologies of oppression, explaining the effects of capitalism on the value of labour, pushing it to the lowest possible level.

This sits well with my research and can also be exemplified in Freire's [25] work regarding oppression, in which he discusses the dehumanisation of the workers. His observations show how people have struggled, and will continue to struggle, to be valued and affirmed as human beings. He argues that 'only power that springs from the weakness of the oppressed will be sufficiently strong to free both' (p 26). Freire focuses on the activist and the women I propose to interview are already active. The role of the activist is to enter the world of the oppressed, facilitating awareness and a critical consciousness of the workers and a sense of their alienation. What can be learned from Freire in the context of these struggles? A theme to be explored is the utility of Freire's idea in the future.

Mockler and Sachs [26] also contribute to the field of activism. Their work focuses on the challenges and changes of teachers' work in the $21^{\text {st }}$ century. They believe that teacher identity has been compromised and that practitioner research is a key to empowering teachers to regain their professionalism. Their work on evidence-based practice and transformational change in schools resonates well with the research of
Hammersley-Fletcher and Qualter [11] and CochranSmith [19].

\section{Methodology}

I am working towards a methodology which enables me to analyse the views of the women teachers who are active in the NUT. In addition, I intend to develop a methodological framework which draws on documentary research and policy analysis. I am continuing to read widely regarding methodologies to inform my proposed research and continue to pursue sensitisation of the relevant documents as they are published. Layder's [27] guidance regarding the lines of enquiry which help to establish links between policy and how it is used in practice, will enable me to focus on how government and NUT policies may influence the participants' responses. I will interview women teachers who are active in the NUT. The interviews will enable me to pursue lines of enquiry back to the documentation, therefore allowing a thorough analysis of the documentation in the light of the lived experiences and struggles of these women.

Because this proposed research is grounded in a sample of NUT women's experiences, I will be developing a feminist methodological framework. Ramazanoglu [28] sets out some of the challenges to feminist social researchers. Although feminist research is committed to science and reason, it is also committed to truth and reality. However, she also argues that a feminist standpoint is complex, stating that it must take account of women's experiences, while also focusing on knowledge of specific gender relations. A feminist standpoint cannot, therefore, be taken from a fixed point, but 'must be grounded in experience of gender subordination and constituted as feminist theory’ (p 69). However, Saul [29] suggests that a feminist standpoint may be construed as a privilege if feminist women are involved as researchers. She believes that 'women, even more than male workers, are said to be in touch with the concrete reality of life' (p 241).

Ramazanoglu [28]also presents the challenges of feminist social research as far as analysing data, where interpretation of the data is under the jurisdiction of the researcher who has the power to represent the participants' contributions. She draws awareness to 'hidden power relations' (p 106) and explains that there will always be an issue of difference between researcher and participants.

The general approach to this research is a qualitative approach. I intend to interview approximately 12 women primary teachers who are active in the NUT. The interviews will be semistructured, allowing respondents to discuss their lived 
experiences. These will be designed to enable the respondents to articulate their concerns in depth. I will analyse the responses of women NUT activists in the primary sector to find out their opinions, fears and hopes, and past and current planned activity they believe are needed, in the current situation. An ethnographic approach will enable me to foster an understanding of the participants' responses as a whole, rather than focusing on the language of their responses alone [30]. Layder [27] also advocates the use of ethnography as it enables the participants to be acknowledged in their own context rather than that of the researcher. A semi-structured interview may be seen to function as a conversation between the interviewer and the interviewee, so it is important that the interviewer's contributions are validated as part of the process. Skeggs [31] states that feminist ethnography was not developed until the latter part of the twentieth century, thus breaking out of the limitations set by male dominance, imperialism and sexism. I therefore intend to follow feminist ethnographic principles in the analysis of the interviews.

A review of recent government educational policy documents will provide context to the struggles that women teachers currently face, together with NUT documentation from Annual Conference proceedings and documentation relating to the standpoints the NUT takes in response to government educational policy. This data will be analysed using critical discourse analysis. If possible, I would like to utilise a computer-based text analysis, as this would be helpful in selecting such elements as potential themes, for example, teacher training, pay and conditions, and pensions, in the policy documents.

\section{References}

[1] National Union of Teachers Annual Conference 2011: The report of the Executive, NUT, London (2011a)

[2] DCSF The Children's Plan, London, (2006).

[3] Department for Education Training our next generation of outstanding teachers, London, (2011).

[4] Department for Education The importance of teaching: The Schools White Paper 2010, London: Stationery Office, (2010).

[5] Blower, C. In defence of teacher education, SCETT, London (2011).

[7] Trades Union Congress TUC Women's Conference 2011: Women against the cuts, Eastbourne, March 2011.

[8] National Union of Teachers (2011b) Annual Conference 2011: Defending education, opposing cuts, protecting pensions, Harrogate, April, 2011.

[9] Ofsted Remodelling the school workforce, Ref no: HMI 2596, London (2005).

[10] DfES Raising standards and tackling workload: a national agreement, London, DfES, (2003).
[11] Hammersley-Fletcher, L. and Qualter, A. Chasing improved pupil performance: the impact of policy change on school educators' perceptions of their professional identity, the case of further change in English schools, British Educational Research Journal, vol 36, no 6, December 2010, p903-917.

[12] Gunter, H. and Rayner, S. Modernizing the school workforce in England: challenging transformation and leadership?, Leadership, vol 3(1), (2006) p47-64.

[13] Hayes, D. In defence of teacher education, SCETT, London. (2011).

[14] Moore, H.L., Feminism and Anthropology, Blackwell, Oxford, (2000).

[15] Blackmore, J. and Kenway, J. Gender matters in educational administration and policy: a feminist introduction, Falmer Press, London (1993).

[16] Connell, R.W. Teachers' work, George, Allen and Unwin, Herts (1985).

[17] Arnot, M. and Mac an Ghaill, M. The Routledge Falmer reader in Gender and Education, Routledge, Oxon, (2007).

[18] Connell, R.W. Gender and power, Polity Press, Cambridge/Blackwell, Oxford, (1993).

[19] Cochran-Smith, M. Policy, practice and politics, Corwin Press and Sage, California, (2006).

[20] Connell, R., Good teachers on dangerous ground: towards a new view of teacher quality and professionalism, Critical Studies in Education, vol 50, no 3, Oct 2009, p213229.

[21] Murray, J. Constructions of caring professionalism: a case study of teacher educators, Gender and Education, vol 18, no 4, July 2006, p381-397.

[22] Blatchford, P., Bassett, P., Brown, P., Martin, C., Russell, A. and Webster, R. The impact of support staff on pupils' 'positive approaches to learning' and their academic progress, British Educational Research Journal, vol 37, no 3, June 2011, p443-464.

[23] Stevenson, H. Restructuring teachers' work and trade union responses in England: Bargaining for change?, American Educational Research Journal, vol 11, no 2, p 224-251.

[24] Davis, M. (ed) Class and gender in British labour history, Merlin Press Ltd, Pontypool, Wales, (2011).

[25] Freire, P. Pedagogy of the oppressed, Penguin, London, (1996).

[26] Mockler, N. and Sachs, J. (Eds) Rethinking Education Practice through reflexive inquiry: Essays in honour of Susan Groundwater Smith, Dordrecht: Springer (2011).

[27] Layder, D. (1996) New strategies in social research, Polity Press, Cambridge, (1996).

[28] Ramazanoglu, C. with Holland, J. Feminist methodology, Sage, London. (2010).

[29] Saul, J. Feminism: issues and arguments, OUP, Oxford, (2003).

[30] Hammersley, M., Gomm, R., Woods, P., Faulkner, D., Swann, J., Baker, S., Bird, M., Carty, J., Mercer, N. and Perrott, M. Research Methods in Education, The Open University, Milton Keynes, (2001).

[31] Skeggs, B. (1994) Situating the production of feminist ethnography (p72) in Maynard, M. and Purvis, J. (eds) (2005) Researching women's lives from a feminist perspective, Taylor and Francis, Oxon, (1994). 